\title{
Causes of and Molecular Targets for the Treatment of Intervertebral Disc Degeneration: A Review
}

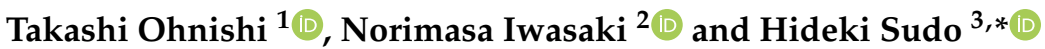 \\ 1 Department of Orthopedic Surgery, Hokkaido University Hospital, Sapporo 060-8648, Japan; \\ takashi.onishi.ortho@gmail.com \\ 2 Department of Orthopedic Surgery, Faculty of Medicine and Graduate School of Medicine, \\ Hokkaido University, Sapporo 060-8638, Japan; niwasaki@med.hokudai.ac.jp \\ 3 Department of Advanced Medicine for Spine and Spinal Cord Disorders, Faculty of Medicine and Graduate \\ School of Medicine, Hokkaido University, Sapporo 060-8638, Japan \\ * Correspondence: hidekisudo@yahoo.co.jp
}

check for updates

Citation: Ohnishi, T.; Iwasaki, N.; Sudo, H. Causes of and Molecular Targets for the Treatment of Intervertebral Disc Degeneration: A Review. Cells 2022, 11, 394. https:// doi.org/10.3390/cells11030394

Academic Editor: Alexander E. Kalyuzhny

Received: 31 December 2021

Accepted: 21 January 2022

Published: 24 January 2022

Publisher's Note: MDPI stays neutral with regard to jurisdictional claims in published maps and institutional affiliations.

Copyright: (c) 2022 by the authors. Licensee MDPI, Basel, Switzerland. This article is an open access article distributed under the terms and conditions of the Creative Commons Attribution (CC BY) license (https:// creativecommons.org/licenses/by/ $4.0 /)$.

\begin{abstract}
Intervertebral disc degeneration (IVDD) is a pathological condition that can lead to intractable back pain or secondary neurological deficits. There is no fundamental cure for this condition, and current treatments focus on alleviating symptoms indirectly. Numerous studies have been performed to date, and the major strategy for all treatments of IVDD is to prevent cell loss due to programmed or regulated cell death. Accumulating evidence suggests that several types of cell death other than apoptosis, including necroptosis, pyroptosis, and ferroptosis, are also involved in IVDD. In this study, we discuss the molecular pathway of each type of cell death and review the literature that has identified their role in IVDD. We also summarize the recent advances in targeted therapy at the RNA level, including RNA modulations through RNA interference and regulation of non-coding RNAs, for preventing cell death and subsequent IVDD. Therefore, we review the causes and possible therapeutic targets for RNA intervention and discuss the future direction of this research field.
\end{abstract}

Keywords: intervertebral disc degeneration; apoptosis; necroptosis; pyroptosis; ferroptosis; small interfering RNA (siRNA); microRNA (miR); long non-coding RNA (lncRNA); circular RNA (circRNA)

\section{Introduction}

Intervertebral discs are located between the vertebrae and confer mobility, load absorbability, and support to the spinal unit [1]. Intervertebral disc degeneration (IVDD) is associated with discogenic low back pain and neurological complications, imposing taxing health problems and a huge economic burden on humans [2,3]. Particularly, the prevalence of low back pain is markedly high worldwide [4]. The mechanism through which IVDD contributes to low back pain is not fully understood; however, several studies have reported the role of aggrecans in nerve and/or blood vessel ingrowth that can be attributed to the generation of nociceptive and neuropathic pain signals. Stefanakis, et al. suggested that the depletion of proteoglycans reduces the internal hydrostatic pressure of the disc and subsequently facilitates blood vessel and nerve ingrowth [5]. In addition, Johnson et al. revealed that chondroitin sulfates of aggrecan inhibit nerve growth. They also stated that the turnover of these proteoglycans to those that possess more keratan sulfates may promote nerve ingrowth to the disc [6]. Recently, Krock et al. reported that degenerating and painful human IVDs release increased levels of nerve growth factors (NGFs), which are inflammatory and nociceptive factors that may induce neo-innervation and pain [7]. Accordingly, IVDD is considered a factor that can induce low back pain.

Currently available treatments include surgeries, such as discectomy and spinal fusion, or medications to alleviate pain [8-10]. The primary problem with these treatments is that they do not address the fundamental underlying pathological conditions but aim to alleviate the symptoms indirectly [8-10]. In addition, their efficacy is not always sufficient 
and can cause adverse side effects, such as relapse of herniation of the nucleus pulposus (NP) [11-13], adjacent segment disease [14], or surgical site infection [15]. Therefore, more direct and effective treatments are needed.

The molecular mechanism underlying IVDD includes DNA replication error, metabolic disorder, and inflammation, and the consequent loss of the disc matrix, functional cells, and stem cells is a characteristic of degenerated discs. DNA replication error occurs secondary to DNA damage response, which leads to cellular senescence [16]. The p53-p21retinoblastoma $(\mathrm{RB})$ protein pathway and $\mathrm{p} 16-\mathrm{RB}$ protein pathway become activated by DNA damage, and this leads to the arrest of cell cycle transition $[16,17]$. Accumulation of senescent cells invokes senescence-associated secretory phenotype that exhibits chronic inflammation and induces degradation of the disc matrix $[18,19]$. Moreover, NP cells are metabolically adapted to a hypoxic and low glucose environment; therefore, they rely on anaerobic glycolysis to generate energy with low reactive oxygen species (ROS) production $[16,20]$. High glucose levels in diabetic patients are known to cause high oxidative stress and induce IVDD [16,21]. Metabolic disorder can also be induced by advanced glycation end product (AGE) accumulation that is associated with IVDD [22]. Degradation and reduction of aggrecan leads to loss of hydration and internal hydrostatic pressure in the NP $[23,24]$. Inflammation leads to aggrecan loss in the NP, and the involvement of interleukin (IL)-1 $\beta$ [25], IL-6 [26,27], IL-17 [28], tumor necrosis factor (TNF)- $\alpha$ [29], and interferon- $\gamma$ [28] in this process has been reported. Among the factors that contribute to IVDD, many of them, including metabolic disorder and inflammation, commonly cause cell death.

Involvement of autophagy in the IVD has been also studied, and this process was found to be a double-edged sword in the development of IVDD, depending on the stimuli [30-32]. Autophagy induced by oxidative stress promoted apoptosis of NP cells [32], and mechanical stress-induced autophagy triggered apoptosis of annulus fibrosus cells [33]. Conversely, autophagy stimulated by hypoxia or metformin exhibited a protective effect against apoptosis of NP cells [31,34]. These previous studies underscore the complex role of autophagy in the development of IVDD, indicating that the regulation of autophagy may be an approach for IVDD treatments.

Numerous studies have been performed to develop novel treatments for IVDD in stages from the bench level to translational research. Biomaterials and cell-based regenerative treatments are attractive tools for reconstituting terminally degenerate matrices to restore function and mitigate pain. However, early diagnosis and minimally invasive treatments are ideal in the initial stage of the disease, and iatrogenic remodeling of the tissue should be preceded by some intervention to prevent the degenerative processes. Therefore, several treatments are based on the strategy of regulating programmed cell death (PCD) [35] and other types of regulated cell death (RCD) [36] (combined as PRCD), as well as targeting autophagy, in the vicinity of intervertebral discs. Especially, evidence of PRCD in IVDD has been reported by several researchers ever since 2000 [37-42]. The loss of local cells is attributed to the attenuated generation of matrix components, such as aggrecan and type II collagen, accompanied by the loss of water aggregated to hyaluronic acid of aggrecan. The reduction of these components coincides with the replacement of the matrix by other fibers, such as type I collagen and fibronectin [43], and other proteoglycans, such as decorin, biglycan, and fibromodulin [44], which results in the formation of a matrix with suboptimal function. To block the initiation of matrix remodeling, presumably local cells of the discs must be maintained. Therapeutic targets to inhibit PRCD have been extensively explored for decades, and this therapeutic principle has become a major strategy to treat IVDD in the early to middle stages $[31,45,46]$. An emerging and actively explored approach in treating IVDD is RNA targeting, including mRNAs and non-coding RNAs (ncRNAs). In this study, we review the molecular signaling pathways of PRCD and molecular targets to suppress these types of cell death, focusing on mRNA interference and modulation of ncRNAs, thereby inhibiting the progression of IVDD. 


\section{Signaling Pathways and Factors Inducing PRCD in Disc Degeneration}

Several types of cell death have been reported to be involved in the occurrence of IVDD. The most well-known PRCD is apoptosis, which is typically triggered by death ligandreceptor binding [47], endoplasmic reticulum (ER) stress [48], and mitochondrial dysfunction secondary to inflammation [49,50], mechanical stress [42], and oxidative stress [51,52]. Other PRCD mechanisms include necroptosis [53-56], pyroptosis [55,57-60], and ferroptosis [61-63]. Historically, apoptosis has been termed PCD, while the others have been termed RCD [35,36]. Each type of PRCD is considered to contribute to the development of IVDD depending on the underlying pathogenesis. In this section, we explain the signaling pathways for each type of PRCD before introducing the therapeutic targets in the next section.

\subsection{Apoptosis}

There are two types of apoptotic signaling pathways-intrinsic and extrinsic pathways [42]. The intrinsic pathway is triggered by cellular stresses such as oxidative stress [51,52], ER stress [48], DNA damage [64], and mitochondrial damage [42]. Following these stimuli, an initiator caspase, caspase-9, binds apoptotic protease activating factor- 1 (Apaf-1) to induce a decline in mitochondrial membrane potential and opening of the mitochondrial permeability transition pore (MPTP) [35]. This leads to the release of mitochondrial cytochrome c, second mitochondria-activator of caspase (Smac/Diablo), high temperature requirement protein $\mathrm{A} 2$ (HtrA2)/Omi, apoptosis-inducing factor (AIF), and endonuclease [42]. Cytochrome $\mathrm{c}$ forms a complex with Apaf-1, procaspase-9, and ATP to form an apoptosome [42]. Apoptosomes recruit the active form of caspase-9 to subsequently cleave and activate the effector caspase caspase-3 to induce apoptosis [35]. Caspase-3 cleaves poly (ADP-ribose) polymerase (PARP) and suppresses its effect to deplete ATP [58]. This is attributed to the maintenance of ATP levels in apoptotic cells [58]. Smac/Diablo and HtraA2/Omi are accessory pro-apoptotic proteins that inhibit inhibitors of apoptosis proteins (IAPs) and help initiate apoptosis $[35,65]$. The release of AIF facilitates nuclear condensation and disrupts chromatin function [42]. Endonuclease activation promotes chromosomal degradation and other processes common between intrinsic and extrinsic pathways, including the destruction of the nuclear proteins and cytoskeleton, crosslinking of proteins, expression of ligands for phagocytic cells, and formation of apoptotic bodies [35]. The extrinsic pathway is initiated by binding of the death ligands and receptors, including TNF and TNF receptor 1 (TNFR1), Fas-L and Fas (alias CD95-ligand and CD95 or APO-1), and TNF-related apoptosis-inducing ligand (TRAIL) and TRAIL receptor 1/2 (alias Apo2-L and TRAIL-R1/2 or DR4) [35]. These ligands are secreted by natural killer cells or macrophages and bind to receptors on the surface of the target cells [35]. The initiator caspase for this pathway is caspase-8. Procaspase-8 interacts with the death domain (DD) that is a cytoplasmic module of death receptor and forms a death-inducing signal complex (DISC), and subsequently cleaves to the active form of caspase-8 [35]. In this process, an adaptor protein, such as Fas-associated death domain (FADD) or TNFR-associated death domain (TRADD) of DISC assists the interaction of procaspase-8 with DISC [35,66]. Dimerized and activated caspase- 8 cleaves effector caspase- 3 with or without the involvement of Smac/Diablo and HtraA2/Omi inhibition of X linked IAP (XIAP), depending on the cell type [67]. Previous studies have provided evidence of both intrinsic and extrinsic pathways in degenerated disc tissue $[37,38,42]$. Specifically, cells of the NP have been reported as type II cells, wherein they undergo the extrinsic apoptotic pathway [37]. Briefly, minute caspase-8 expression activates Bid (BH3 interacting domain death agonist) but does not activate caspase- 3 directly; Bid heterodimerizing with Bax and Bak, and antagonized Bcl-2 and mitochondrial membrane permeability increases and pro-apoptotic proteins egress to the cytoplasm. The signaling following this is similar to the intrinsic pathway that recruits caspase-9 [37,67] (See Figure 1). 


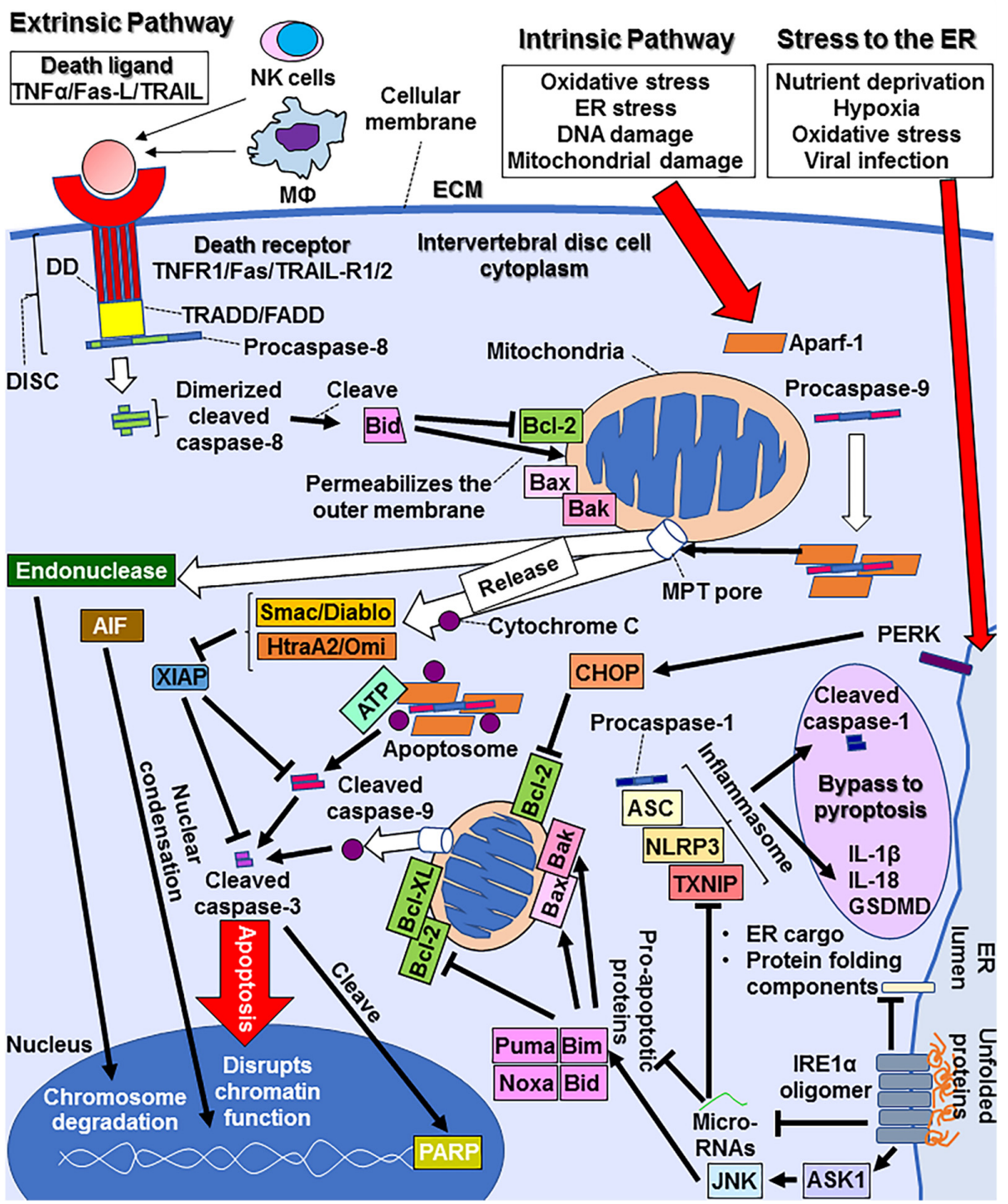

Figure 1. A scheme of apoptotic signaling pathways. AIF, apoptosis-inducing factor; Apaf-1, apoptotic protease activating factor-1; ASC, apoptosis-associated speck-like protein; ASK1, apoptosissignal-regulating kinase 1; CHOP, C/EBP homologous protein; DD, death domain; DISC, deathinducing signal complex; ECM, extracellular matrix; ER, endoplasmic reticulum; FADD, Fasassociated death domain; GSDMD, gasdermin-D; IRE1 $\alpha$, inositol-requiring enzyme $1 \alpha$; JNK, c-Jun NH2-terminal kinase; NLRP3, nucleotide-binding oligomerization domain (NOD)-like receptors family pyrin domain containing 3; PARP, poly (ADP-ribose) polymerase; PERK, pancreatic endoplasmic reticulum kinase; TNFR, TNF receptor; TRADD, TNFR-associated death domain; TRAIL, TNF-related apoptosis-inducing ligand; TRAILR, TRAIL receptor; TXNIP, thioredoxin-interacting protein; XIAP, X linked inhibitors of apoptosis protein.

Apoptosis is induced by several factors. One representative model of injury-induced IVDD is the needle puncture model [10,68-70]. In a rabbit model of IVDD generated by needle puncture, Fas expression was evident only in the punctured discs, and Fas- $\mathrm{L}$ expression was augmented in the punctured discs than in the control discs [71], indicating that injury can cause Fas-L-Fas binding to initiate apoptosis. An increase in the expression of inflammatory cytokines, such as IL-6, TNF $\alpha$, and IL-1 $\beta$, has been observed in a rat tail disc puncture model [72]. Considering the existence of TNFR1 and TNFR2 in NP [73], TNF $\alpha$-TNFR binding can also lead to apoptosis in cells of the NP. Biomechanical overload is a major cause of apoptosis [74-76]. In an in vitro compression model of human NP cells, 
the involvement of the intrinsic pathway of apoptosis, represented by elevated Bax and decreased Bcl-2, was elucidated [77]. Increased levels of oxidative stress result in apoptosis via the intrinsic pathway owing to compression [76]. Because mitochondria are the main source of ROS, compression-induced damage to mitochondria results in the enhanced generation of ROS in the cytoplasm and contributes to increased oxidative stress and apoptosis of NP mesenchymal stem cells via the intrinsic pathway [34,42,76]. The opening of the MPTP is composed of an adenine nucleotide translocator (ANT), cyclophilin-D (CYP-D), and voltage-dependent anion channel (VDAC), which increases the permeability of the mitochondrial membrane [42]. The detrimental outcomes include suppression of the respiratory chain and the release of pro-apoptotic proteins, including cytochrome c [42]. In addition, miRNA-34a-5p is reported to participate in compression-induced degeneration by repressing silent mating type information regulation 2 homolog 1 (SIRT1), which is a critical regulator of cell differentiation, proliferation, and apoptosis [77]. ER stress is another factor that triggers the apoptotic signaling cascade. The basic role of ER stress is to restore homeostasis in the ER and protect cells [33,78]. However, if the stress is excessive or persistent, ER dysfunction may not completely recover, resulting in apoptosis [33,48]. Factors, such as nutrient deprivation, hypoxia, oxidative stress, and viral infection may induce protein misfolding or disarray in calcium homeostasis, leading to ER stress [33,79]. Initially, a signaling pathway called the homeostatic unfolded protein response (UPR) attempts to correct this condition [78,79]. Three ER transmembrane proteins, namely, inositol-requiring enzyme $1 \alpha$ (IRE1 $\alpha)$, pancreatic endoplasmic reticulum kinase (PERK), and activating transcription factor 6 (ATF6) sense misfolded proteins at critically high concentrations $[48,78,79]$. IRE1 $\alpha$ and PERK have ER-luminal domains that can dimerize and initiate the UPR; however, in the unstressed state, their binding with the ER chaperone BiP suppresses the UPR $[79,80]$. Unfolded proteins can titrate BiP and bind to the ER luminal domain to initiate the UPR $[48,79]$. When homeostatic UPR fails to restore the condition by increasing ER size, chaperone biogenesis, degradation of misfolded proteins, and slowing down protein translation, the signaling platform transforms to a terminal UPR [78,79]. Hyperactivated IRE1 $\alpha$ forms an ER-luminal domain oligomer, which allows RNase to degrade mRNAs that are not appropriate substrates, such as ER cargo and protein-folding components, and worsens ER stress [48,79]. In addition, RNase insult leads to a reduction in microRNAs that suppress pro-apoptotic proteins, including thioredoxininteracting protein (TXNIP) [79]. The upregulation of TXNIP results in the activation of the inflammasome and caspase-1-dependent pro-death pathway [79]. BH3-only proteins (Bid, Bim, Noxa, and Puma) are also affected by these miRNAs and are upregulated [79]. They inactivate mitochondrial-protecting proteins, such as Bcl-2 and Bcl-XL, and activate pro-apoptotic proteins, such as Bax and Bak, that permeabilize the outer mitochondrial membrane [79]. Another signaling pathway involved is the apoptosis-signal-regulating kinase 1 (ASK1)-c-Jun NH2-terminal kinase (JNK) axis, which activates Bim and inhibits Bcl-2 [48,79]. Sustained PERK activation upregulates the transcription factor C/EBP homologous protein (CHOP), which suppresses the expression of anti-apoptotic Bcl-2 to promote cell death [78,79] (See Figure 1). In the disc field, the accumulation of AGEs is reported to induce ER stress through dysregulated $\mathrm{Ca}^{2+}$ homeostasis in aged and degenerated discs, especially in diabetic patients [22].

\subsection{Necroptosis}

Necroptosis is a type of RCD characterized by necrosis [35]. When the cell is unable to enter apoptosis and death ligand binds to the receptor, pro-survival complex I forms [56], comprising TRADD/FADD, receptor-interacting proteins (RIP) 1, and several ubiquitin E3 ligases [54]. Deubiquitination of RIP1 results in the formation of complex IIa or IIb [35,56]. The turning point between subsequent apoptosis and necroptosis is determined by whether or not caspase- 8 is inhibited [35]. When caspase- 8 can become activated, complex IIa forms and activates caspase-8, triggering apoptosis [55]. However, complex IIb formation leads to necroptosis $[35,55]$. It involves the formation of a complex called necrosome consisting 
of TRADD/FADD, caspase-8, RIP1, and phosphorylated RIP3; RIP3 phosphorylates mixed lineage kinase domain-like pseudokinase (MLKL) [81], which oligomerizes and translocates to the cytoplasmic membrane from the cytoplasm to perforate pores and causes cell lysis, thereby resulting in necroptosis [35,54] (See Figure 2). RIP1/RIP3/MLKL-mediated necroptosis has been reported in compression-induced rat NP cell death [53] and in herniated human NP tissue and cells [81]. Therefore, necroptosis occurs in the vicinity of intervertebral discs.

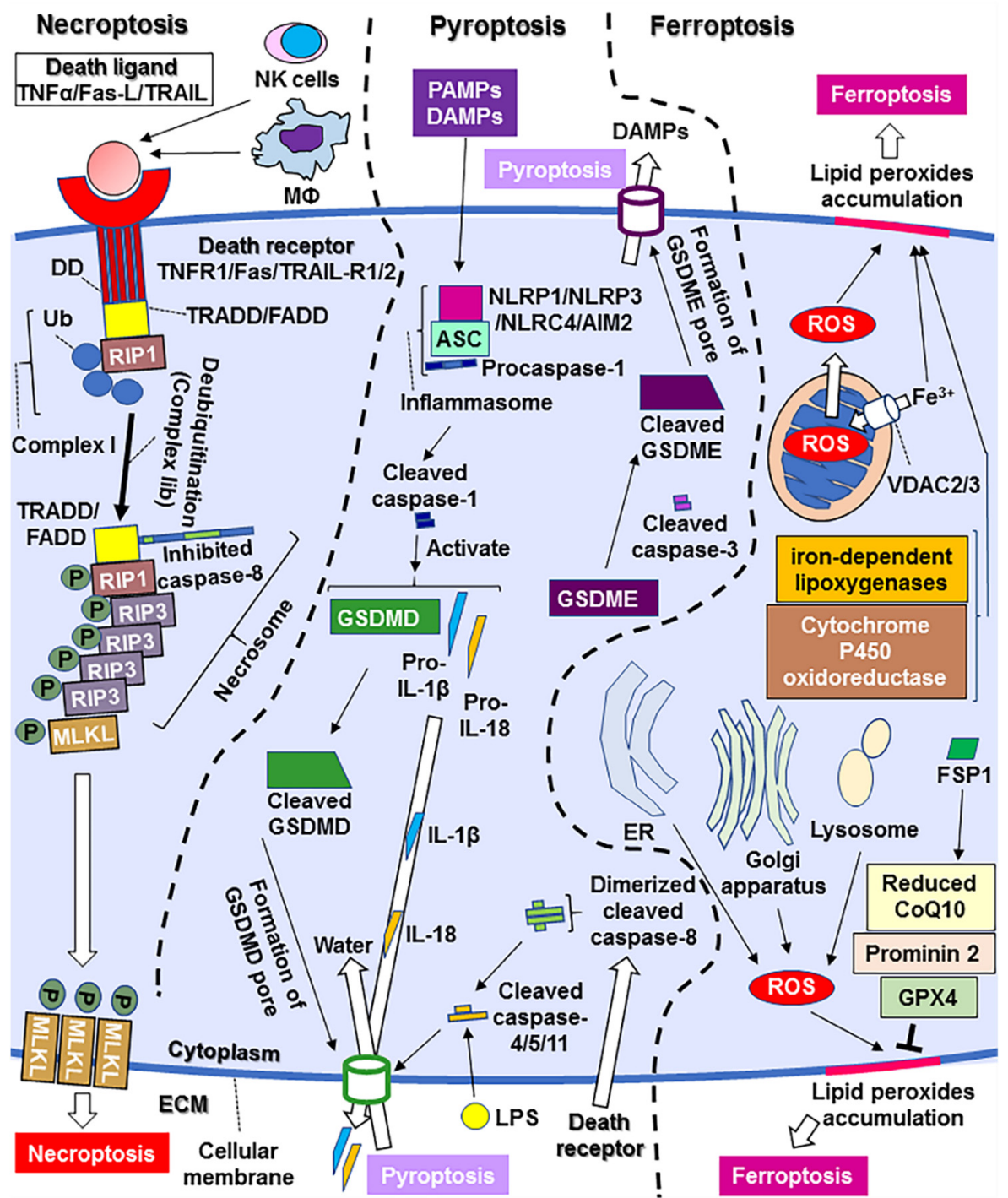

Figure 2. A scheme of necroptotic, pyroptotic, and ferroptotic signaling pathways. AIM2, absent in melanoma 2; ASC, apoptosis-associated speck-like protein; CoQ10, coenzyme Q10; DAMPs, damageassociated molecular patterns; DD, death domain; ECM, extracellular matrix; ER, endoplasmic reticulum; FADD, Fas-associated death domain; FSP, ferroptosis suppressor protein; GPX, glutathione peroxidase; GSDMD, gasdermin-D; GSDME, gasdermin-E; LPS, lipopolysaccharide; MLKL, mixed lineage kinase domain-like pseudokinase; NLRP, nucleotide-binding oligomerization domain (NOD)like receptors family pyrin domain containing; NLRC, NOD-like receptors family caspase recruitment domain containing; PAMPs, pathogen-associated molecular patterns; PARP, poly (ADP-ribose) polymerase; PERK, pancreatic endoplasmic reticulum kinase; RIP, receptor-interacting proteins; ROS, reactive oxygen species; TNFR, TNF receptor; TRADD, TNFR-associated death domain; TRAIL, TNF-related apoptosis-inducing ligand; TRAILR, TRAIL receptor; TXNIP, thioredoxin-interacting protein; $\mathrm{Ub}$, ubiquitination; XIAP, $\mathrm{X}$ linked inhibitors of apoptosis protein. 


\subsection{Pyroptosis}

Pyroptosis is an inflammatory form of RCD [58]. Pattern-recognition receptors (PRRs) include toll-like receptors (TLRs), nucleotide-binding oligomerization domain (NOD)like receptors (NLRP1, NLRP3, and NLRC4), and absent in melanoma 2 (AIM2)-like receptors (ALRs); they constitute inflammasomes with apoptosis-associated speck-like protein (ASC) and pro-caspase-1 [60]. When PRRs recognize certain pathogen-associated molecular patterns induced by exogenous pathogens and damage-associated molecular patterns (DAMPs) derived from endogenous pathogens, inflammasomes lead to activation of caspase- 1 , and subsequent activation of interleukin (IL)-1 $\beta$, IL-18, and gasdermin-D (GSDMD) [82]. The cleaved N-terminal fragment of GSDMD forms pores in the plasma membrane, leading to excess extracellular secretion of ILs and intracellular water flux, resulting in cell swelling and lysis $[58,60]$. Lipopolysaccharide (LPS) from gram-negative bacteria may also directly activate caspase- $4 / 5 / 11$ to cleave GSDMD and form plasma membrane pores [60]. In addition, GSDMD cleavage can be induced through the activation of caspase- $4 / 5 / 11$ by death receptor stimuli and caspase- 8 activation $[59,60]$. The executor of apoptosis, caspase-3, has also been found to cleave gasdermin-E (GSDME), which can also perforate the plasma membrane [55]. In this case, both the stimulation of death receptors and the efflux of pro-apoptotic proteins from the mitochondria result in pyroptosis as well as apoptosis (See Figure 2). The relevance of pyroptosis in intervertebral discs was reported in the presence of Propionibacterium acnes infection [83], wherein the NLRP3 inflammasome was suggested to contribute to the induction of pyroptosis through TXNIP [83]. TXNIP inhibits thioredoxin and increases intracellular ROS production [83]. Another condition involving NLRP3-mediated pyroptosis is injury-induced disc degeneration [84]. Decreased levels of miR-410 were found in needle-punctured discs and miR-410 was implicated as a negative mediator of NP cell pyroptosis [84]. Although controversial, lactate accumulation may be responsible for NLRP3 inflammasome-mediated pyroptosis in degenerated disc tissue $[85,86]$. Injection of exogenous lactate has been shown to stimulate acid-sensing ion channel (ASIC) 1 and 3 to promote intracellular transportation of $\mathrm{Ca}^{2+}$, leading to an increase in intracellular ROS levels in NP cells [86]. Moreover, enhanced intracellular $\mathrm{Ca}^{2+}$ signaling has been suggested to be associated with the augmentation of ROS and NLRP3 inflammasome activation in blood cells [57]. Similar results have been demonstrated in NP cells wherein ASIC1 and ASIC 3 induced NLRP3 inflammasome activation and pyroptosis in NP cells via upregulation of the ROS/NF- $\kappa \mathrm{B}$ signaling pathway, followed by increased expression of inflammasome components [86].

\subsection{Ferroptosis}

Ferroptosis is a necrotic form of RCD characterized by lipid peroxidation and free ironmediated Fenton reactions [87]. Cells undergoing ferroptosis accumulate lipid peroxides and are deficient in the defense system required to eliminate them, leading to their accumulation to lethal levels [36]. Ferroptotic cells exhibit necrotic morphology, small dysmorphic mitochondria with decreased crista, a condensed membrane, and a ruptured outer membrane $[36,62,88]$. It has been shown using the small molecule erastin that mitochondrial VDACs $2 / 3$ open and take up iron, and iron-induced ROS generation results in elevated mitochondrial potential and oxidative stress-induced ferroptosis [89]. ER-derived oxidative stress, Golgi stress-related lipid peroxidation, and lysosomal dysfunction are attributed to ferroptosis $[90,91]$. Other factors include lipid peroxide generation by iron-dependent lipoxygenases and further propagation of peroxides by labile iron [36,92]. Cytochrome P450 oxidoreductase has also been reported to be a driver of lipid peroxidation during ferroptosis $[36,93]$. Glutathione peroxidase (GPX) 4 is a representative suppressor of ferroptosis; it prevents the accumulation of peroxidized lipids [36]. Ferritin contributes to a decrease in free iron which is supplied through VDAC 2/3 [36]. Prominin 2 sabotages polyunsaturated fatty acyl phospholipids that are crucial for iron-dependent lipid peroxidation [36]. Coenzyme Q10 (CoQ10) is a part of the mitochondrial electron transport chain; reduced CoQ10 can trap lipid peroxides and prevent ferroptosis outside the mitochondria $[36,63]$. 
Ferroptosis suppressor protein (FSP) 1 reduces CoQ10 and decreases lipid peroxides [63] (See Figure 2). The major implications of ferroptosis in disease are found in cancer as well as in the nervous system and digestive system disorders $[61,62,94]$. Ferroptosis has also been implicated in the vicinity of intervertebral discs [87]. The levels of GPX4 and ferritin heavy chain were lower in the degenerated disc tissues of a rat model of IVDD than in those of healthy rats [87]. In addition, ferroptosis may also be attributed to injury-induced disc degeneration because the degenerative processes have been shown to be attenuated by deferoxamine, an inhibitor of ferroptosis, in a rat model of IVDD [87].

\section{Targets to Regulate PRCD to Prevent Disc Degeneration}

In this section, we review previously studied therapeutic targets to prevent cell loss due to PRCD and the consequent IVDD, focusing on siRNA and ncRNAs.

\subsection{Small Interfering RNA (siRNA)}

Small interfering RNAs (siRNAs) are often targeted for inhibiting certain genes at the transcriptional level $[95,96]$. The executor of apoptosis, caspase-3 is an effective target to inhibit cell death [70]. Previous studies have shown caspase-3 siRNA to be effective for not only inhibiting apoptosis in cultured NP cells, but also as a therapeutic reagent to prevent injury-induced or biomechanical overload-induced IVDD [68,70,74]. Another study showed the modulation of CHOP, a product of ER stress, by CHOP-siRNA, as well as a significant reduction in the rate of apoptosis, ROS level, lysosome activity, and expression of PARP, Caspase-12, Caspase-3, LC3, Beclin-1, and CHOP, in an in vitro cyclic deformation stress model [33]. Yes-associated protein 1 (YAP1), a transcriptional co-activator and negative regulator of the Hippo pathway, regulates cell proliferation, contact inhibition, and tissue size [97]. Chen et al. reported that YAP1 is activated by IL-6 through tyrosine phosphorylation, and YAP1 knockdown by siRNA increased Sox-9, type II collagen, and aggrecan expression in IL-6-treated NP cells [97]. Notably, IL-6 was shown to enhance YAP1- $\beta$-catenin interaction and nuclear accumulation, and $\beta$-catenin knockdown by siRNA has been shown to block IL-6 treatment or YAP1 overexpression induced degenerative consequences [97]. The YAP1 inhibitor verteporfin was used in an injury-induced disc degeneration model and partially rescued type II collagen and inhibited MMP-13 [97]. TXNIP, an endogenous inhibitor of thioredoxin, produces excessive ROS and causes cellular oxidative stress; high levels of TXNIP accompanied by inflammasome activation have been found in degenerated discs [83]. In an in vitro NP cell co-culture system with P. acnes, targeting of the TXNIP/NLRP3 signaling pathway using the NLRP3 inflammasome inhibitor MCC950 and TXNIP-siRNA led to reduced secretion of mature IL-1 $\beta$ and IL-18 [83]. The efficacy of MCC950 was further established in vivo in a rabbit model of IVDD with P. acnes infection, which showed an alleviatory effect of MCC950 on the degenerative process [83]. Lactate accumulation is an important factor in disc degeneration [86]. In vitro, lactate exposure to NP cells enhanced pyroptosis, and NLRP3-siRNA or ASIC inhibitors successfully blocked lactate-induced NLRP3 inflammasome activation [86]. As explained in the previous section, extracellular lactate controls the levels of intercellular ROS through ASIC1 and ASIC3 [86]. ROS activates the NF- $\mathrm{KB}$ signaling pathway and upregulates the expression of NLRP3 inflammasome components and IL-1 $\beta$ release [86]; therefore, NLRP3-siRNA and ASIC inhibitor treatment inhibit pyroptosis. A comparative analysis of the miRNA profiles of NP cells collected from healthy subjects and those with degenerative discs revealed that bone morphogenetic protein (BMP) 2 is a target of miR-129-5p, and downregulation of miR-129-5p expression is a risk factor for IVDD as it promotes apoptosis in NP cells [98]. NP cells treated with miR-129-5p mimics or BMP2-siRNA exhibited improved viability and lower apoptosis rates than the control groups [98]. The Fas death receptor is a therapeutic target for inhibiting apoptosis via the extrinsic pathway. A previous study has shown a reduction in apoptosis and improved annulus fibrosus cell proliferation with Fas-siRNA in a serum starvation model [99]. Bim, a member of the BH3 subfamily of the Bcl-2 family is also targeted for inhibiting apoptosis. Bim has been found to be a direct target of miR-25-3p, 
which was downregulated in NP cells in degenerative discs [100]. miR-25-3p inhibition decreased NP cell proliferation and induced cell apoptosis but Bim-siRNA inhibited apoptosis [100]. The application of Bim-siRNA may also be an attractive treatment for preventing apoptosis and subsequent IVDD. Therefore, targeting various pro-apoptotic molecules through silencing via the siRNA approach is an effective method to prevent IVDD.

\section{2. ncRNAs}

NcRNAs are a group of RNAs that regulate mRNAs, including microRNAs, long ncRNAs (lncRNAs), and circular RNAs (circRNAs) [101]. Intriguingly, evidence has shown that ncRNAs play an important role in the occurrence of disc degeneration.

MiR-486-5p has been shown to be significantly lower in degenerated discs than in controls [102]. Another study revealed that miR-486-5p directly targets fork head box protein $\mathrm{O} 1$ (FOXO1), which regulates the expression of inflammatory cytokines and plays a vital role in apoptosis [102]. Thus, the upregulation of miR-486-5p may be a strategy for inhibiting cell death and disc degeneration. MiR-141 is another miRNA that is known to be agonistic to NP cell apoptosis [103]. MiR-141 was found to deplete SIRT1, a negative regulator of the NF-kB pathway, and knocking out miR-141 attenuated spontaneous and surgically induced IVDD [103]. MiR-141 may therefore be a potential target for preventing disc degeneration. MiR-138-5p [30,104] and miR-34a-5p [77] also negatively affect SIRT1. Another miRNA, miR-27a overexpression induces apoptosis of human degenerated NP cells by silencing phosphatidylinositol 3-kinase (PI3K) [30]. The PI3K/protein kinase B (Akt) pathway determines cell fate by modulating cell proliferation, apoptosis, autophagy, and differentiation [30]. Therefore, miR-27a inhibition may be an attractive strategy for preventing cell death in degenerative discs [30]. MiR-494 has also been shown to promote NP cell apoptosis $[105,106]$ by negatively regulating JunD and subsequently promoting the secretion of pro-apoptotic proteins from the mitochondria [105,106], making it a candidate therapeutic target for the prevention of degenerative cell loss. In contrast, the expression of miR-155 has been found to be low in degenerative human NP cells $[105,107]$, whereas its overexpression resulted in the downregulation of FADD and caspase- 3 and subsequent decrease in Fas-mediated apoptosis in human NP cells [105,107]. MiR-532 was found to be upregulated in degenerated discs, and treatment with miR-532 mimics increased NP cell apoptosis [108]. MiR-532 was shown to downregulate Wnt/ $\beta$-catenin signaling via targeting Bcl-9, therefore leading to NP cell apoptosis [108]. MiR-185 binds to and negatively regulates Galectin-3, which is highly expressed in NP cells of degenerated discs [109]. As a simulation of degenerated disc conditions, the effects of miR-185 inhibition were assessed and found to increase Galectin-3, pro-autophagy factors LC3 and Beclin-1, pro-apoptosis factors caspase- 3 and Bax, as well as the Wnt/ $\beta$-catenin signaling pathway [109]. Notably, miR-185 agomir injection alleviated the degenerative processes induced in the instability model [109]. MiR-210 is known to regulate apoptosis and its expression levels were found to be lower in patients with degenerative discs than in those with non-degenerate discs [110]. When NP cells treated with FasL were additionally treated with pre-miR-210, the number of apoptotic cells significantly decreased [110], suggesting a protective role of miR-210 against apoptosis through the extrinsic pathway. MiR-410 is known to be an important negative mediator of pyroptosis and acts by suppressing the NLRP3/caspase-1 pathway [84]. Therefore, $\mathrm{miR}-410$ may be a potential target for regulating pyroptosis in NP cells. MiR-222 is also upregulated in human degenerative disc tissues [111]. In vitro, apoptosis was promoted and inhibited and the production of TNF- $\alpha$, IL-1 $\beta$, IL-6, TLR4, p-IкB $\alpha$, and p-p65 were upregulated and downregulated by miR-222 mimics and miR-222 inhibitors, respectively [111]. Moreover, tissue inhibitor of metalloproteinase 3 (TIMP3), a suppressor of matrix degradation was elucidated to be a direct target of miR-222 [111]. Therefore, miR-222 inhibitor may be ideal for suppressing cell death and preserving extracellular matrix integrity, including that of intervertebral discs. Besides the aforementioned mRNAs, several other miRNAs, including miR-21 [112], miR-499a-5p [113], miR-125a [114], miR-145 [115], and miR-573 [116] are anti-apoptotic, and miRNAs including miR-30d [117], 
miR-222-3p [118], miR-15a [119], miR-143 [120], miR-106a-5p [121], and miR-221 [122,123], are also pro-apoptotic. As mentioned in the previous section, miR-129-5p prevents apoptosis of NP cells by targeting BMP2 [98], and miR-25-3p protects NP cells from apoptosis, whereas Bim siRNA can be an option to disinhibit miR-25-3p [100]. In conclusion, agomirs and antagomirs of miRNAs whose low and high expression, respectively, is associated with disc degeneration can be used for their upregulation and downregulation, respectively, to prevent the death of NP cells and subsequentIVDD.

The lncRNA RP11-296A18.3 has been implicated in excess NP cell apoptosis; it has been found to be upregulated in degenerative discs [124,125]. HLA complex group 18 (HCG18) is another lncRNA that has been found to be upregulated in NP tissues from herniated or bulging discs [124,126]; HCG18 acts as an endogenous sponge for miR-146a-5p to inhibit cell proliferation, promote apoptosis, and enhance the release of chemoattractants for macrophages in NP cells $[124,126]$. Such upregulated lncRNAs can be targeted for inhibiting disc degeneration. In contrast, metastasis-associated lung adenocarcinoma transcript 1 (MALAT1 alias, NEAT2) is a lncRNA that is downregulated in NP cells isolated from degenerative discs [124,127]. MALAT1 has been shown to inhibit caspase-3 activity and secretion of IL-1 and IL-6 [124,127]; hence, it can be therapeutically enhanced to prevent disc degeneration. The lncRNA prostate androgen-regulated transcript 1 (PART1) has been reported to promote disc degeneration by downregulating the miR-93/MMP2 pathway in NP cells [128,129]. A study showed that PART1 knockdown enhances cell viability, reduces cell apoptosis, inhibits inflammatory factor secretion, and promotes matrix degradation in LPS-stimulated NP cells in vitro [128]. Further studies revealed that PART1 sponges miR-190a-3p and downregulates its expression [128]. Therefore, PART1 inhibition or miR190a-3p overexpression may be an option to prevent apoptosis. TUG1 is a pro-apoptotic IncRNA that upregulates the levels of Bax and caspase- 3 in the Wnt $1 / \beta$-catenin pathway and downregulates the levels of Bcl-2 [122,130]. GAS5 and lncPolE are pro-apoptotic lncRNAs that are overexpressed in degenerative discs [122,131,132]. GAS5 sequesters to miR-155 and lncPolE downregulates PolE to promote apoptosis [122,131,132]. Therefore, lncRNA can be inhibited or overexpressed to prevent NC cell apoptosis and thereby, IVDD.

CircVMA21, circRNA derived from the vacuolar ATPase assembly factor (VMA21) gene targets miR-200c, and circVMA21 indirectly affects XIAP through miR-200c [133]. CircVMA21 is known to act as a sponge for miR-200c, which exhibits tumor suppressive and apoptosis-inducing behavior [133]. MiR-200c inhibits XIAP and reduces NP cell viability, and direct injection of circVMA21 in intervertebral discs was found to alleviate NP cell apoptosis and IVDD [133]. CircRNA involved in compression-induced damage of NP cells (circRNA-CIDN) have been found to be downregulated in compression-treated human NP cells and circRNA-CIDN overexpression inhibited compression-induced apoptosis in NP cells [77]. Further investigation revealed that circRNA-CIDN acts as a sponge for miR-34a-5p, which plays a detrimental role in compression-induced damage of NP cells by repressing SIRT1 [77]. In contrast, circRNA_104670 acts as a sponge for miR-17-3p, abrogating its protective role in NP cell apoptosis $[77,134]$.

\section{Future Directions and Conclusions}

IVDD is a formidable health problem that is associated with back pain [2], spinal segment instability [135,136], and secondary neurological deficits [137]. One of the intractable problems associated with IVDD is the lack of fundamental treatment. Numerous studies on the treatment of IVDD have been performed worldwide, and the major principle of all therapeutic strategies is the prevention of cell loss due to excessive PRCD by targeting mRNAs [33,70], ncRNAs [77,100], hormones [46,138], proteins related to PRCD [139,140], autophagy [141,142], and cellular homeostasis [82,143] or utilizing vitamins [73,144], natural compounds [145,146], growth factors [147,148], synthetic drugs [31,76], and traditional Chinese medicine $[149,150]$. In this study, we summarized the molecular pathways of PRCD and the molecular targets that can be modulated at the mRNA level to suppress PCD and other types of RCD. 
However, there exist several difficulties in applying these RNA interventions for preventing IVDD in clinical settings, and they must be addressed. Early-stage interventions cannot be highly invasive because patients with early to middle stage IVDD may not exhibit severe symptoms or disability. However, to prevent the progression of IVDD, interventions during the window of opportunity should be important. New approaches, such as novel drug delivery systems, may need to be explored to realize early-stage treatments for IVDD. Further research is necessary to improve the quality of life of patients.

Author Contributions: Conceptualization, T.O., N.I. and H.S.; investigation, T.O.; writing-original draft preparation, T.O.; writing—review and editing, T.O., N.I. and H.S.; supervision, N.I. and H.S.; funding acquisition, H.S. All authors have read and agreed to the published version of the manuscript.

Funding: This work was supported by funds for "Project for Regenerative/Cellular Medicine and Gene Therapies" from the Japan Agency for Medical Research and Development (JP21bm0404068h0002) and grants-in-aid from the Ministry of Education, Culture, Sports, Science, and Technology of Japan (21H03313).

Acknowledgments: The sponsor of the study had no role in the report preparation.

Conflicts of Interest: The authors declare no conflict of interest.

\section{References}

1. Shapiro, I.M.; Vresilovic, E.J.; Risbud, M.V. Is the spinal motion segment a diarthrodial polyaxial joint: What a nice nucleus like you doing in a joint like this? Bone 2012, 50, 771-776. [CrossRef] [PubMed]

2. The US Burden of Disease Collaborators; Mokdad, A.H.; Ballestros, K.; Echko, M.; Glenn, S.; Olsen, H.E.; Mullany, E.; Lee, A.; Khan, A.R.; Ahmadi, A.; et al. The State of US Health, 1990-2016: Burden of Diseases, Injuries, and Risk Factors Among US States. JAMA 2018, 319, 1444-1472. [CrossRef] [PubMed]

3. Ohnishi, T.; Novais, E.J.; Risbud, M.V. Alterations in ECM signature underscore multiple sub-phenotypes of intervertebral disc degeneration. Matrix Biol. Plus 2020, 6-7, 100036. [CrossRef] [PubMed]

4. Livshits, G.; Popham, M.; Malkin, I.; Sambrook, P.N.; Macgregor, A.J.; Spector, T.; Williams, F.M.K. Lumbar disc degeneration and genetic factors are the main risk factors for low back pain in women: The UK Twin Spine Study. Ann. Rheum. Dis. 2011, 70, 1740-1745. [CrossRef]

5. Stefanakis, M.; Al-Abbasi, M.; Harding, I.; Pollintine, P.; Dolan, P.; Tarlton, J.; Adams, M.A. Annulus fissures are mechanically and chemically conducive to the ingrowth of nerves and blood vessels. Spine 2012, 37, 1883-1891. [CrossRef]

6. Johnson, W.E.; Caterson, B.; Eisenstein, S.M.; Hynds, D.L.; Snow, D.M.; Roberts, S. Human intervertebral disc aggrecan inhibits nerve growth in vitro. Arthritis Rheum. 2002, 46, 2658-2664. [CrossRef]

7. Krock, E.; Rosenzweig, D.H.; Chabot-Dore, A.J.; Jarzem, P.; Weber, M.H.; Ouellet, J.A.; Stone, L.S.; Haglund, L. Painful, degenerating intervertebral discs up-regulate neurite sprouting and CGRP through nociceptive factors. J. Cell Mol. Med. 2014, 18, 1213-1225. [CrossRef]

8. Ohnishi, T.; Sudo, H.; Tsujimoto, T.; Iwasaki, N. Age-related spontaneous lumbar intervertebral disc degeneration in a mouse model. J. Orthop. Res. 2018, 36, 224-232. [CrossRef]

9. Vo, N.; Niedernhofer, L.J.; Nasto, L.A.; Jacobs, L.; Robbins, P.D.; Kang, J.; Evans, C.H. An overview of underlying causes and animal models for the study of age-related degenerative disorders of the spine and synovial joints. J. Orthop. Res. 2013, 31, 831-837. [CrossRef]

10. Ohnishi, T.; Sudo, H.; Iwasaki, K.; Tsujimoto, T.; Ito, Y.M.; Iwasaki, N. In Vivo Mouse Intervertebral Disc Degeneration Model Based on a New Histological Classification. PLoS ONE 2016, 11, e0160486. [CrossRef]

11. Tsujimoto, T.; Sudo, H.; Todoh, M.; Yamada, K.; Iwasaki, K.; Ohnishi, T.; Hirohama, N.; Nonoyama, T.; Ukeba, D.; Ura, K.; et al. An acellular bioresorbable ultra-purified alginate gel promotes intervertebral disc repair: A preclinical proof-of-concept study. EBioMedicine 2018, 37, 521-534. [CrossRef] [PubMed]

12. Ukeba, D.; Sudo, H.; Tsujimoto, T.; Ura, K.; Yamada, K.; Iwasaki, N. Bone marrow mesenchymal stem cells combined with ultrapurified alginate gel as a regenerative therapeutic strategy after discectomy for degenerated intervertebral discs. EBioMedicine 2020, 53, 102698. [CrossRef] [PubMed]

13. Shin, E.H.; Cho, K.J.; Kim, Y.T.; Park, M.H. Risk factors for recurrent lumbar disc herniation after discectomy. Int. Orthop. 2018, 43, 963-967. [CrossRef] [PubMed]

14. Phan, K.; Nazareth, A.; Hussain, A.K.; Dmytriw, A.A.; Nambiar, M.; Nguyen, D.; Kerferd, J.; Phan, S.; Sutterlin, C., 3rd; Cho, S.K.; et al. Relationship between sagittal balance and adjacent segment disease in surgical treatment of degenerative lumbar spine disease: Meta-analysis and implications for choice of fusion technique. Eur. Spine J. 2018, 27, 1981-1991. [CrossRef]

15. Takahashi, J.; Shono, Y.; Hirabayashi, H.; Kamimura, M.; Nakagawa, H.; Ebara, S.; Kato, H. Usefulness of white blood cell differential for early diagnosis of surgical wound infection following spinal instrumentation surgery. Spine 2006, 31, 1020-1025. [CrossRef] 
16. Wang, F.; Cai, F.; Shi, R.; Wang, X.H.; Wu, X.T. Aging and age related stresses: A senescence mechanism of intervertebral disc degeneration. Osteoarthr. Cartil. 2016, 24, 398-408. [CrossRef]

17. Novais, E.J.; Diekman, B.O.; Shapiro, I.M.; Risbud, M.V. p16(Ink4a) deletion in cells of the intervertebral disc affects their matrix homeostasis and senescence associated secretory phenotype without altering onset of senescence. Matrix Biol. 2019, 82, 54-70. [CrossRef]

18. Coppe, J.P.; Patil, C.K.; Rodier, F.; Sun, Y.; Munoz, D.P.; Goldstein, J.; Nelson, P.S.; Desprez, P.Y.; Campisi, J. Senescence-associated secretory phenotypes reveal cell-nonautonomous functions of oncogenic RAS and the p53 tumor suppressor. PLoS Biol. 2008, 6, 2853-2868. [CrossRef]

19. Cherif, H.; Bisson, D.G.; Mannarino, M.; Rabau, O.; Ouellet, J.A.; Haglund, L. Senotherapeutic drugs for human intervertebral disc degeneration and low back pain. Elife 2020, 9, e54693. [CrossRef]

20. Lee, D.C.; Adams, C.S.; Albert, T.J.; Shapiro, I.M.; Evans, S.M.; Koch, C.J. In situ oxygen utilization in the rat intervertebral disc. J. Anat. 2007, 210, 294-303. [CrossRef]

21. Fields, A.J.; Berg-Johansen, B.; Metz, L.N.; Miller, S.; La, B.; Liebenberg, E.C.; Coughlin, D.G.; Graham, J.L.; Stanhope, K.L.; Havel, P.J.; et al. Alterations in intervertebral disc composition, matrix homeostasis and biomechanical behavior in the UCD-T2DM rat model of type 2 diabetes. J. Orthop. Res. 2015, 33, 738-746. [CrossRef] [PubMed]

22. Luo, R.; Song, Y.; Liao, Z.; Yin, H.; Zhan, S.; Wang, K.; Li, S.; Li, G.; Ma, L.; Lu, S.; et al. Impaired calcium homeostasis via advanced glycation end products promotes apoptosis through endoplasmic reticulum stress in human nucleus pulposus cells and exacerbates intervertebral disc degeneration in rats. FEBS J. 2019, 286, 4356-4373. [CrossRef] [PubMed]

23. Capossela, S.; Schläfli, P.; Bertolo, A.; Janner, T.; Stadler, B.M.; Pötzel, T.; Baur, M.; Stoyanov, J.V. Degenerated human intervertebral discs contain autoantibodies against extracellular matrix proteins. Eur. Cells Mater. 2014, 27, 251-263, discussion 263. [CrossRef] [PubMed]

24. Jin, L.; Liu, Q.; Scott, P.; Zhang, D.; Shen, F.; Balian, G.; Li, X. Annulus fibrosus cell characteristics are a potential source of intervertebral disc pathogenesis. PLoS ONE 2014, 9, e96519. [CrossRef]

25. Yang, W.; Yu, X.H.; Wang, C.; He, W.S.; Zhang, S.J.; Yan, Y.G.; Zhang, J.; Xiang, Y.X.; Wang, W.J. Interleukin-1 $\beta$ in intervertebral disk degeneration. Clin. Chim. Acta 2015, 450, 262-272. [CrossRef]

26. Suzuki, S.; Fujita, N.; Fujii, T.; Watanabe, K.; Yagi, M.; Tsuji, T.; Ishii, K.; Miyamoto, T.; Horiuchi, K.; Nakamura, M.; et al. Potential Involvement of the IL-6/JAK/STAT3 Pathway in the Pathogenesis of Intervertebral Disc Degeneration. Spine 2017, 42, E817-E824. [CrossRef]

27. Risbud, M.V.; Shapiro, I.M. Role of cytokines in intervertebral disc degeneration: Pain and disc content. Nat. Rev. Rheumatol. 2014, 10, 44-56. [CrossRef]

28. Shamji, M.F.; Setton, L.A.; Jarvis, W.; So, S.; Chen, J.; Jing, L.; Bullock, R.; Isaacs, R.E.; Brown, C.; Richardson, W.J. Proinflammatory cytokine expression profile in degenerated and herniated human intervertebral disc tissues. Arthritis Rheum. 2010, 62, 1974-1982. [CrossRef]

29. Le Maitre, C.L.; Freemont, A.J.; Hoyland, J.A. Accelerated cellular senescence in degenerate intervertebral discs: A possible role in the pathogenesis of intervertebral disc degeneration. Arthritis Res. Ther. 2007, 9, R45. [CrossRef]

30. Ouyang, Z.H.; Wang, W.J.; Yan, Y.G.; Wang, B.; Lv, G.H. The PI3K/Akt pathway: A critical player in intervertebral disc degeneration. Oncotarget 2017, 8, 57870-57881. [CrossRef]

31. Chen, D.; Xia, D.; Pan, Z.; Xu, D.; Zhou, Y.; Wu, Y.; Cai, N.; Tang, Q.; Wang, C.; Yan, M.; et al. Metformin protects against apoptosis and senescence in nucleus pulposus cells and ameliorates disc degeneration in vivo. Cell Death Dis. 2016, 7, e2441. [CrossRef] [PubMed]

32. Chen, J.W.; Ni, B.B.; Li, B.; Yang, Y.H.; Jiang, S.D.; Jiang, L.S. The responses of autophagy and apoptosis to oxidative stress in nucleus pulposus cells: Implications for disc degeneration. Cell Physiol. Biochem. 2014, 34, 1175-1189. [CrossRef] [PubMed]

33. Chen, J.; Lin, Z.; Deng, K.; Shao, B.; Yang, D. Tension induces intervertebral disc degeneration via endoplasmic reticulum stress-mediated autophagy. Biosci. Rep. 2019, 39. [CrossRef] [PubMed]

34. He, R.; Wang, Z.; Cui, M.; Liu, S.; Wu, W.; Chen, M.; Wu, Y.; Qu, Y.; Lin, H.; Chen, S.; et al. HIF1A Alleviates compression-induced apoptosis of nucleus pulposus derived stem cells via upregulating autophagy. Autophagy 2021, 11, 3338-3360. [CrossRef] [PubMed]

35. D'Arcy, M.S. Cell death: A review of the major forms of apoptosis, necrosis and autophagy. Cell Biol. Int. 2019, 43, 582-592. [CrossRef] [PubMed]

36. Stockwell, B.R.; Jiang, X.; Gu, W. Emerging Mechanisms and Disease Relevance of Ferroptosis. Trends Cell Biol. 2020, 30, 478-490. [CrossRef]

37. Park, J.B.; Lee, J.K.; Park, S.J.; Kim, K.W.; Riew, K.D. Mitochondrial involvement in fas-mediated apoptosis of human lumbar disc cells. J. Bone Jt. Surg. 2005, 87, 1338-1342. [CrossRef]

38. Rannou, F.; Lee, T.S.; Zhou, R.H.; Chin, J.; Lotz, J.C.; Mayoux-Benhamou, M.A.; Barbet, J.P.; Chevrot, A.; Shyy, J.Y. Intervertebral disc degeneration: The role of the mitochondrial pathway in annulus fibrosus cell apoptosis induced by overload. Am. J. Pathol. 2004, 164, 915-924. [CrossRef]

39. Ariga, K.; Miyamoto, S.; Nakase, T.; Okuda, S.; Meng, W.; Yonenobu, K.; Yoshikawa, H. The relationship between apoptosis of endplate chondrocytes and aging and degeneration of the intervertebral disc. Spine 2001, 26, 2414-2420. [CrossRef] 
40. Zhao, C.Q.; Jiang, L.S.; Dai, L.Y. Programmed cell death in intervertebral disc degeneration. Apoptosis 2006, 11, 2079-2088. [CrossRef]

41. Zhao, C.Q.; Wang, L.M.; Jiang, L.S.; Dai, L.Y. The cell biology of intervertebral disc aging and degeneration. Ageing Res. Rev. 2007, 6, 247-261. [CrossRef] [PubMed]

42. Ding, F.; Shao, Z.W.; Yang, S.H.; Wu, Q.; Gao, F.; Xiong, L.M. Role of mitochondrial pathway in compression-induced apoptosis of nucleus pulposus cells. Apoptosis 2012, 17, 579-590. [CrossRef] [PubMed]

43. Yee, A.; Lam, M.P.; Tam, V.; Chan, W.C.; Chu, I.K.; Cheah, K.S.; Cheung, K.M.; Chan, D. Fibrotic-like changes in degenerate human intervertebral discs revealed by quantitative proteomic analysis. Osteoarthr. Cartil. 2016, 24, 503-513. [CrossRef] [PubMed]

44. Erwin, W.M.; DeSouza, L.; Funabashi, M.; Kawchuk, G.; Karim, M.Z.; Kim, S.; Mädler, S.; Matta, A.; Wang, X.; Mehrkens, K.A. The biological basis of degenerative disc disease: Proteomic and biomechanical analysis of the canine intervertebral disc. Arthritis Res. Ther. 2015, 17, 240. [CrossRef] [PubMed]

45. Chen, Y.; Lin, J.; Chen, J.; Huang, C.; Zhang, Z.; Wang, J.; Wang, K.; Wang, X. Mfn2 is involved in intervertebral disc degeneration through autophagy modulation. Osteoarthr. Cartil. 2020, 28, 363-374. [CrossRef]

46. Chen, Y.; Wu, Y.; Shi, H.; Wang, J.; Zheng, Z.; Chen, J.; Chen, X.; Zhang, Z.; Xu, D.; Wang, X.; et al. Melatonin ameliorates intervertebral disc degeneration via the potential mechanisms of mitophagy induction and apoptosis inhibition. J. Cell Mol. Med. 2019, 23, 2136-2148. [CrossRef]

47. Igney, F.H.; Krammer, P.H. Death and anti-death: Tumour resistance to apoptosis. Nat. Rev. Cancer 2002, 2, 277-288. [CrossRef]

48. Wang, S.; Kaufman, R.J. The impact of the unfolded protein response on human disease. J. Cell Biol. 2012, 197, 857-867. [CrossRef]

49. Ansari, M.Y.; Khan, N.M.; Ahmad, I.; Haqqi, T.M. Parkin clearance of dysfunctional mitochondria regulates ROS levels and increases survival of human chondrocytes. Osteoarthr. Cartil. 2018, 26, 1087-1097. [CrossRef]

50. Madhu, V.; Guntur, A.R.; Risbud, M.V. Role of autophagy in intervertebral disc and cartilage function: Implications in health and disease. Matrix Biol. 2020, 100, 207-220. [CrossRef]

51. Kim, S.H.; Kim, H. Inhibitory Effect of Astaxanthin on Oxidative Stress-Induced Mitochondrial Dysfunction-A Mini-Review. Nutrients 2018, 10, 1137. [CrossRef] [PubMed]

52. Kudryavtseva, A.V.; Krasnov, G.S.; Dmitriev, A.A.; Alekseev, B.Y.; Kardymon, O.L.; Sadritdinova, A.F.; Fedorova, M.S.; Pokrovsky, A.V.; Melnikova, N.V.; Kaprin, A.D.; et al. Mitochondrial dysfunction and oxidative stress in aging and cancer. Oncotarget 2016, 7 , 44879-44905. [CrossRef]

53. Chen, S.; Lv, X.; Hu, B.; Shao, Z.; Wang, B.; Ma, K.; Lin, H.; Cui, M. RIPK1/RIPK3/MLKL-mediated necroptosis contributes to compression-induced rat nucleus pulposus cells death. Apoptosis 2017, 22, 626-638. [CrossRef] [PubMed]

54. Gong, Y.; Fan, Z.; Luo, G.; Yang, C.; Huang, Q.; Fan, K.; Cheng, H.; Jin, K.; Ni, Q.; Yu, X.; et al. The role of necroptosis in cancer biology and therapy. Mol. Cancer 2019, 18, 100. [CrossRef]

55. Tang, R.; Xu, J.; Zhang, B.; Liu, J.; Liang, C.; Hua, J.; Meng, Q.; Yu, X.; Shi, S. Ferroptosis, necroptosis, and pyroptosis in anticancer immunity. J. Hematol. Oncol. 2020, 13, 110. [CrossRef]

56. Yuan, J.; Amin, P.; Ofengeim, D. Necroptosis and RIPK1-mediated neuroinflammation in CNS diseases. Nat. Rev. Neurosci. 2019, 20, 19-33. [CrossRef] [PubMed]

57. Chae, J.J.; Park, Y.H.; Park, C.; Hwang, I.Y.; Hoffmann, P.; Kehrl, J.H.; Aksentijevich, I.; Kastner, D.L. Connecting two pathways through Ca 2+ signaling: NLRP3 inflammasome activation induced by a hypermorphic PLCG2 mutation. Arthritis Rheumatol. 2015, 67, 563-567. [CrossRef] [PubMed]

58. Fang, Y.; Tian, S.; Pan, Y.; Li, W.; Wang, Q.; Tang, Y.; Yu, T.; Wu, X.; Shi, Y.; Ma, P.; et al. Pyroptosis: A new frontier in cancer Biomed. Pharmacother. 2020, 121, 109595. [CrossRef]

59. Frank, D.; Vince, J.E. Pyroptosis versus necroptosis: Similarities, differences, and crosstalk. Cell Death Differ. 2019, 26, 99-114. [CrossRef]

60. Xia, X.; Wang, X.; Cheng, Z.; Qin, W.; Lei, L.; Jiang, J.; Hu, J. The role of pyroptosis in cancer: Pro-cancer or pro-“host”? Cell Death Dis. 2019, 10, 650. [CrossRef]

61. Carlson, B.A.; Tobe, R.; Yefremova, E.; Tsuji, P.A.; Hoffmann, V.J.; Schweizer, U.; Gladyshev, V.N.; Hatfield, D.L.; Conrad, M. Glutathione peroxidase 4 and vitamin E cooperatively prevent hepatocellular degeneration. Redox Biol. 2016, 9, 22-31. [CrossRef] [PubMed]

62. Dixon, S.J.; Lemberg, K.M.; Lamprecht, M.R.; Skouta, R.; Zaitsev, E.M.; Gleason, C.E.; Patel, D.N.; Bauer, A.J.; Cantley, A.M.; Yang, W.S.; et al. Ferroptosis: An iron-dependent form of nonapoptotic cell death. Cell 2012, 149, 1060-1072. [CrossRef] [PubMed]

63. Tang, D.; Chen, X.; Kang, R.; Kroemer, G. Ferroptosis: Molecular mechanisms and health implications. Cell Res. 2021, 31, 107-125. [CrossRef] [PubMed]

64. Wang, J.Y.J. Cell Death Response to DNA Damage. Yale J. Biol. Med. 2019, 92, 771-779.

65. Ekert, P.G.; Vaux, D.L. The mitochondrial death squad: Hardened killers or innocent bystanders? Curr. Opin. Cell Biol. 2005, 17, 626-630. [CrossRef]

66. Kim, J.H.; Lee, S.Y.; Oh, S.Y.; Han, S.I.; Park, H.G.; Yoo, M.A.; Kang, H.S. Methyl jasmonate induces apoptosis through induction of Bax/Bcl-XS and activation of caspase-3 via ROS production in A549 cells. Oncol. Rep. 2004, 12, 1233-1238. [CrossRef]

67. Kantari, C.; Walczak, H. Caspase-8 and bid: Caught in the act between death receptors and mitochondria. Biochim. Biophys. Acta 2011, 1813, 558-563. [CrossRef] 
68. Ohnishi, T.; Yamada, K.; Iwasaki, K.; Tsujimoto, T.; Higashi, H.; Kimura, T.; Iwasaki, N.; Sudo, H. Caspase-3 knockout inhibits intervertebral disc degeneration related to injury but accelerates degeneration related to aging. Sci. Rep. 2019, 9, 19324. [CrossRef]

69. Masuda, K.; Aota, Y.; Muehleman, C.; Imai, Y.; Okuma, M.; Thonar, E.J.; Andersson, G.B.; An, H.S. A novel rabbit model of mild, reproducible disc degeneration by an anulus needle puncture: Correlation between the degree of disc injury and radiological and histological appearances of disc degeneration. Spine 2005, 30, 5-14. [CrossRef]

70. Sudo, H.; Minami, A. Caspase 3 as a therapeutic target for regulation of intervertebral disc degeneration in rabbits. Arthritis Rheum. 2011, 63, 1648-1657. [CrossRef]

71. Wang, J.; Tang, T.; Yang, H.; Yao, X.; Chen, L.; Liu, W.; Li, T. The expression of Fas ligand on normal and stabbed-disc cells in a rabbit model of intervertebral disc degeneration: A possible pathogenesis. J. Neurosurg. Spine 2007, 6, 425-430. [CrossRef]

72. Chan, A.K.; Tang, X.; Mummaneni, N.V.; Coughlin, D.; Liebenberg, E.; Ouyang, A.; Dudli, S.; Lauricella, M.; Zhang, N.; Waldorff, E.I.; et al. Pulsed electromagnetic fields reduce acute inflammation in the injured rat-tail intervertebral disc. JOR Spine 2019, 2, e1069. [CrossRef] [PubMed]

73. Wang, C.; Yu, X.; Yan, Y.; Yang, W.; Zhang, S.; Xiang, Y.; Zhang, J.; Wang, W. Tumor necrosis factor- $\alpha$ : A key contributor to intervertebral disc degeneration. Acta Biochim. Biophys. Sin. 2017, 49, 1-13. [CrossRef] [PubMed]

74. Yamada, K.; Sudo, H.; Iwasaki, K.; Sasaki, N.; Higashi, H.; Kameda, Y.; Ito, M.; Takahata, M.; Abumi, K.; Minami, A.; et al. Caspase 3 silencing inhibits biomechanical overload-induced intervertebral disk degeneration. Am. J. Pathol. 2014, 184, 753-764. [CrossRef] [PubMed]

75. Hirata, H.; Yurube, T.; Kakutani, K.; Maeno, K.; Takada, T.; Yamamoto, J.; Kurakawa, T.; Akisue, T.; Kuroda, R.; Kurosaka, M.; et al. A rat tail temporary static compression model reproduces different stages of intervertebral disc degeneration with decreased notochordal cell phenotype. J. Orthop. Res. 2014, 32, 455-463. [CrossRef]

76. Hu, Y.; Huang, L.; Shen, M.; Liu, Y.; Liu, G.; Wu, Y.; Ding, F.; Ma, K.; Wang, W.; Zhang, Y.; et al. Pioglitazone Protects CompressionMediated Apoptosis in Nucleus Pulposus Mesenchymal Stem Cells by Suppressing Oxidative Stress. Oxid. Med. Cell Longev. 2019, 2019, 4764071. [CrossRef] [PubMed]

77. Xiang, Q.; Kang, L.; Wang, J.; Liao, Z.; Song, Y.; Zhao, K.; Wang, K.; Yang, C.; Zhang, Y. CircRNA-CIDN mitigated compression loading-induced damage in human nucleus pulposus cells via miR-34a-5p/SIRT1 axis. EBioMedicine 2020, 53, 102679. [CrossRef]

78. Ron, D.; Walter, P. Signal integration in the endoplasmic reticulum unfolded protein response. Nat. Rev. Mol. Cell Biol. 2007, 8, 519-529. [CrossRef]

79. Oakes, S.A.; Papa, F.R. The role of endoplasmic reticulum stress in human pathology. Annu. Rev. Pathol. 2015, 10, 173-194. [CrossRef]

80. Abu-Id, M.H.; Warnke, P.H.; Gottschalk, J.; Springer, I.; Wiltfang, J.; Acil, Y.; Russo, P.A.; Kreusch, T. 'Bis-phossy jaws'—High and low risk factors for bisphosphonate-induced osteonecrosis of the jaw. J. Craniomaxillofac. Surg. 2008, 36, 95-103. [CrossRef]

81. Zhang, Q.X.; Guo, D.; Wang, F.C.; Ding, W.Y. Necrosulfonamide (NSA) protects intervertebral disc degeneration via necroptosis and apoptosis inhibition. Eur. Rev. Med. Pharmacol. Sci. 2020, 24, 2683-2691. [CrossRef]

82. Kamali, A.; Ziadlou, R.; Lang, G.; Pfannkuche, J.; Cui, S.; Li, Z.; Richards, R.G.; Alini, M.; Grad, S. Small molecule-based treatment approaches for intervertebral disc degeneration: Current options and future directions. Theranostics 2021, 11, 27-47. [CrossRef] [PubMed]

83. He, D.; Zhou, M.; Bai, Z.; Wen, Y.; Shen, J.; Hu, Z. Propionibacterium acnes induces intervertebral disc degeneration by promoting nucleus pulposus cell pyroptosis via NLRP3-dependent pathway. Biochem. Biophys. Res. Commun. 2020, 526, 772-779. [CrossRef]

84. Zhang, J.; Zhang, J.; Zhang, Y.; Liu, W.; Ni, W.; Huang, X.; Yuan, J.; Zhao, B.; Xiao, H.; Xue, F. Mesenchymal stem cells-derived exosomes ameliorate intervertebral disc degeneration through inhibiting pyroptosis. J. Cell Mol. Med. 2020, 24, 11742-11754. [CrossRef] [PubMed]

85. Wu, W.; Zhang, X.; Hu, X.; Wang, X.; Sun, L.; Zheng, X.; Jiang, L.; Ni, X.; Xu, C.; Tian, N.; et al. Lactate down-regulates matrix systhesis and promotes apoptosis and autophagy in rat nucleus pulposus cells. J. Orthop. Res. 2014, 32, 253-261. [CrossRef] [PubMed]

86. Zhao, K.; An, R.; Xiang, Q.; Li, G.; Wang, K.; Song, Y.; Liao, Z.; Li, S.; Hua, W.; Feng, X.; et al. Acid-sensing ion channels regulate nucleus pulposus cell inflammation and pyroptosis via the NLRP3 inflammasome in intervertebral disc degeneration. Cell Prolif. 2021, 54, e12941. [CrossRef] [PubMed]

87. Yang, R.Z.; Xu, W.N.; Zheng, H.L.; Zheng, X.F.; Li, B.; Jiang, L.S.; Jiang, S.D. Involvement of oxidative stress-induced annulus fibrosus cell and nucleus pulposus cell ferroptosis in intervertebral disc degeneration pathogenesis. J. Cell Physiol. 2021, 236, 2725-2739. [CrossRef]

88. Friedmann Angeli, J.P.; Schneider, M.; Proneth, B.; Tyurina, Y.Y.; Tyurin, V.A.; Hammond, V.J.; Herbach, N.; Aichler, M.; Walch, A.; Eggenhofer, E.; et al. Inactivation of the ferroptosis regulator Gpx4 triggers acute renal failure in mice. Nat. Cell Biol. 2014, 16, 1180-1191. [CrossRef]

89. Maldonado, E.N.; Sheldon, K.L.; DeHart, D.N.; Patnaik, J.; Manevich, Y.; Townsend, D.M.; Bezrukov, S.M.; Rostovtseva, T.K.; Lemasters, J.J. Voltage-dependent anion channels modulate mitochondrial metabolism in cancer cells: Regulation by free tubulin and erastin. J. Biol. Chem. 2013, 288, 11920-11929. [CrossRef]

90. Wu, Y.; Zhang, S.; Gong, X.; Tam, S.; Xiao, D.; Liu, S.; Tao, Y. The epigenetic regulators and metabolic changes in ferroptosisassociated cancer progression. Mol. Cancer 2020, 19, 39. [CrossRef] 
91. Sun, Y.; Chen, P.; Zhai, B.; Zhang, M.; Xiang, Y.; Fang, J.; Xu, S.; Gao, Y.; Chen, X.; Sui, X.; et al. The emerging role of ferroptosis in inflammation. Biomed. Pharmacother. 2020, 127, 110108. [CrossRef] [PubMed]

92. Shah, R.; Shchepinov, M.S.; Pratt, D.A. Resolving the Role of Lipoxygenases in the Initiation and Execution of Ferroptosis. ACS Cent. Sci. 2018, 4, 387-396. [CrossRef] [PubMed]

93. Zou, Y.; Li, H.; Graham, E.T.; Deik, A.A.; Eaton, J.K.; Wang, W.; Sandoval-Gomez, G.; Clish, C.B.; Doench, J.G.; Schreiber, S.L. Cytochrome P450 oxidoreductase contributes to phospholipid peroxidation in ferroptosis. Nat. Chem. Biol. 2020, 16, 302-309. [CrossRef] [PubMed]

94. Nobuta, H.; Yang, N.; Ng, Y.H.; Marro, S.G.; Sabeur, K.; Chavali, M.; Stockley, J.H.; Killilea, D.W.; Walter, P.B.; Zhao, C.; et al. Oligodendrocyte Death in Pelizaeus-Merzbacher Disease Is Rescued by Iron Chelation. Cell Stem Cell 2019, 25, 531-541.e6. [CrossRef]

95. Kumar, L.D.; Clarke, A.R. Gene manipulation through the use of small interfering RNA (siRNA): From in vitro to in vivo applications. Adv. Drug Deliv. Rev. 2007, 59, 87-100. [CrossRef] [PubMed]

96. Fire, A.; Xu, S.; Montgomery, M.K.; Kostas, S.A.; Driver, S.E.; Mello, C.C. Potent and specific genetic interference by doublestranded RNA in Caenorhabditis elegans. Nature 1998, 391, 806-811. [CrossRef] [PubMed]

97. Chen, J.; Mei, Z.; Huang, B.; Zhang, X.; Liu, J.; Shan, Z.; Wang, J.; Wang, X.; Zhao, F. IL-6/YAP1/ $\beta$-catenin signaling is involved in intervertebral disc degeneration. J. Cell Physiol. 2019, 234, 5964-5971. [CrossRef]

98. Yang, W.; Sun, P. Downregulation of microRNA-129-5p increases the risk of intervertebral disc degeneration by promoting the apoptosis of nucleus pulposus cells via targeting BMP2. J. Cell Biochem. 2019, 120, 19684-19690. [CrossRef]

99. Zhang, X.B.; Hu, Y.C.; Cheng, P.; Zhou, H.Y.; Chen, X.Y.; Wu, D.; Zhang, R.H.; Yu, D.C.; Gao, X.D.; Shi, J.T.; et al. Targeted therapy for intervertebral disc degeneration: Inhibiting apoptosis is a promising treatment strategy. Int. J. Med. Sci. 2021, 18, 2799-2813. [CrossRef]

100. Zhao, Z.; Zheng, J.; Ye, Y.; Zhao, K.; Wang, R.; Wang, R. MicroRNA-25-3p regulates human nucleus pulposus cell proliferation and apoptosis in intervertebral disc degeneration by targeting Bim. Mol. Med. Rep. 2020, 22, 3621-3628. [CrossRef]

101. Panni, S.; Lovering, R.C.; Porras, P.; Orchard, S. Non-coding RNA regulatory networks. Biochim. Biophys. Acta Gene Regul. Mech. 2020, 1863, 194417. [CrossRef] [PubMed]

102. Chai, X.; Si, H.; Song, J.; Chong, Y.; Wang, J.; Zhao, G. miR-486-5p Inhibits Inflammatory Response, Matrix Degradation and Apoptosis of Nucleus Pulposus Cells through Directly Targeting FOXO1 in Intervertebral Disc Degeneration. Cell Physiol. Biochem. 2019, 52, 109-118. [CrossRef] [PubMed]

103. Ji, M.L.; Jiang, H.; Zhang, X.J.; Shi, P.L.; Li, C.; Wu, H.; Wu, X.T.; Wang, Y.T.; Wang, C.; Lu, J. Preclinical development of a microRNA-based therapy for intervertebral disc degeneration. Nat. Commun. 2018, 9, 5051. [CrossRef] [PubMed]

104. Wang, B.; Wang, D.; Yan, T.; Yuan, H. MiR-138-5p promotes TNF- $\alpha$-induced apoptosis in human intervertebral disc degeneration by targeting SIRT1 through PTEN/PI3K/Akt signaling. Exp. Cell Res. 2016, 345, 199-205. [CrossRef]

105. Wang, C.; Wang, W.J.; Yan, Y.G.; Xiang, Y.X.; Zhang, J.; Tang, Z.H.; Jiang, Z.S. MicroRNAs: New players in intervertebral disc degeneration. Clin. Chim. Acta 2015, 450, 333-341. [CrossRef]

106. Wang, T.; Li, P.; Ma, X.; Tian, P.; Han, C.; Zang, J.; Kong, J.; Yan, H. MicroRNA-494 inhibition protects nucleus pulposus cells from TNF- $\alpha$-induced apoptosis by targeting JunD. Biochimie 2015, 115, 1-7. [CrossRef]

107. Wang, H.Q.; Yu, X.D.; Liu, Z.H.; Cheng, X.; Samartzis, D.; Jia, L.T.; Wu, S.X.; Huang, J.; Chen, J.; Luo, Z.J. Deregulated miR-155 promotes Fas-mediated apoptosis in human intervertebral disc degeneration by targeting FADD and caspase-3. J. Pathol. 2011, 225, 232-242. [CrossRef]

108. Sun, Z.; Jian, Y.; Fu, H.; Li, B. MiR-532 downregulation of the Wnt/ $\beta$-catenin signaling via targeting Bcl-9 and induced human intervertebral disc nucleus pulposus cells apoptosis. J. Pharmacol. Sci. 2018, 138, 263-270. [CrossRef]

109. Yun, Z.; Wang, Y.; Feng, W.; Zang, J.; Zhang, D.; Gao, Y. Overexpression of microRNA-185 alleviates intervertebral disc degeneration through inactivation of the Wnt/ $\beta$-catenin signaling pathway and downregulation of Galectin-3. Mol. Pain 2020, 16, 1744806920902559. [CrossRef]

110. Zhang, D.Y.; Wang, Z.J.; Yu, Y.B.; Zhang, Y.; Zhang, X.X. Role of microRNA-210 in human intervertebral disc degeneration. Exp. Ther. Med. 2016, 11, 2349-2354. [CrossRef]

111. Zhang, Y.; Yang, J.; Zhou, X.; Wang, N.; Li, Z.; Zhou, Y.; Feng, J.; Shen, D.; Zhao, W. Knockdown of miR-222 inhibits inflammation and the apoptosis of LPS-stimulated human intervertebral disc nucleus pulposus cells. Int. J. Mol. Med. 2019, 44, 1357-1365. [CrossRef]

112. Cheng, X.; Zhang, G.; Zhang, L.; Hu, Y.; Zhang, K.; Sun, X.; Zhao, C.; Li, H.; Li, Y.M.; Zhao, J. Mesenchymal stem cells deliver exogenous miR-21 via exosomes to inhibit nucleus pulposus cell apoptosis and reduce intervertebral disc degeneration. J. Cell Mol. Med. 2018, 22, 261-276. [CrossRef] [PubMed]

113. Sun, J.C.; Zheng, B.; Sun, R.X.; Meng, Y.K.; Wang, S.M.; Yang, H.S.; Chen, Y.; Shi, J.G.; Guo, Y.F. MiR-499a-5p suppresses apoptosis of human nucleus pulposus cells and degradation of their extracellular matrix by targeting SOX4. Biomed. Pharmacother. 2019, 113, 108652. [CrossRef] [PubMed]

114. Ma, J.F.; Zang, L.N.; Xi, Y.M.; Yang, W.J.; Zou, D. MiR-125a Rs12976445 Polymorphism is Associated with the Apoptosis Status of Nucleus Pulposus Cells and the Risk of Intervertebral Disc Degeneration. Cell Physiol. Biochem. 2016, 38, 295-305. [CrossRef] [PubMed] 
115. Zhou, J.; Sun, J.; Markova, D.Z.; Li, S.; Kepler, C.K.; Hong, J.; Huang, Y.; Chen, W.; Xu, K.; Wei, F.; et al. MicroRNA-145 overexpression attenuates apoptosis and increases matrix synthesis in nucleus pulposus cells. Life Sci. 2019, 221, 274-283. [CrossRef] [PubMed]

116. Wang, R.; Wen, B.; Sun, D. miR-573 regulates cell proliferation and apoptosis by targeting Bax in nucleus pulposus cells. Cell Mol. Biol. Lett. 2019, 24, 2. [CrossRef]

117. Lv, J.; Li, S.; Wan, T.; Yang, Y.; Cheng, Y.; Xue, R. Inhibition of microRNA-30d attenuates the apoptosis and extracellular matrix degradation of degenerative human nucleus pulposus cells by up-regulating SOX9. Chem. Biol. Interact. 2018, $296,89-97$. [CrossRef]

118. Liu, J.; Yu, J.; Jiang, W.; He, M.; Zhao, J. Targeting of CDKN1B by miR-222-3p may contribute to the development of intervertebral disc degeneration. FEBS Open Bio. 2019, 9, 728-735. [CrossRef]

119. Cai, P.; Yang, T.; Jiang, X.; Zheng, M.; Xu, G.; Xia, J. Role of miR-15a in intervertebral disc degeneration through targeting MAP3K9. Biomed. Pharmacother. 2017, 87, 568-574. [CrossRef]

120. Zhao, K.; Zhang, Y.; Kang, L.; Song, Y.; Wang, K.; Li, S.; Wu, X.; Hua, W.; Shao, Z.; Yang, S.; et al. Epigenetic silencing of miRNA-143 regulates apoptosis by targeting BCL2 in human intervertebral disc degeneration. Gene 2017, 628, 259-266. [CrossRef]

121. Hai, B.; Ma, Y.; Pan, X.; Yong, L.; Liang, C.; He, G.; Yang, C.; Zhu, B.; Liu, X. Melatonin benefits to the growth of human annulus fibrosus cells through inhibiting miR-106a-5p/ATG7 signaling pathway. Clin. Interv. Aging 2019, 14, 621-630. [CrossRef] [PubMed]

122. Guo, H.Y.; Guo, M.K.; Wan, Z.Y.; Song, F.; Wang, H.Q. Emerging evidence on noncoding-RNA regulatory machinery in intervertebral disc degeneration: A narrative review. Arthritis Res. Ther. 2020, 22, 270. [CrossRef] [PubMed]

123. Sheng, B.; Yuan, Y.; Liu, X.; Zhang, Y.; Liu, H.; Shen, X.; Liu, B.; Chang, L. Protective effect of estrogen against intervertebral disc degeneration is attenuated by miR-221 through targeting estrogen receptor $\alpha$. Acta Biochim. Biophys. Sin. 2018, 50, 345-354. [CrossRef]

124. Li, Z.; Li, X.; Chen, C.; Li, S.; Shen, J.; Tse, G.; Chan, M.T.V.; Wu, W.K.K. Long non-coding RNAs in nucleus pulposus cell function and intervertebral disc degeneration. Cell Prolif. 2018, 51, e12483. [CrossRef] [PubMed]

125. Wang, X.; Lv, G.; Li, J.; Wang, B.; Zhang, Q.; Lu, C. LncRNA-RP11-296A18.3/miR-138/HIF1A Pathway Regulates the Proliferation ECM Synthesis of Human Nucleus Pulposus Cells (HNPCs). J. Cell Biochem. 2017, 118, 4862-4871. [CrossRef] [PubMed]

126. Xi, Y.; Jiang, T.; Wang, W.; Yu, J.; Wang, Y.; Wu, X.; He, Y. Long non-coding HCG18 promotes intervertebral disc degeneration by sponging miR-146a-5p and regulating TRAF6 expression. Sci. Rep. 2017, 7, 13234. [CrossRef] [PubMed]

127. Zhang, H.; Li, J.; Duan, D.; She, W.; Wang, L.; Zhang, F. The role of lncRNA MALAT1 in intervertebral degenerative disc disease. Int. J. Clin. Exp. Pathol. 2017, 10, 10611-10617.

128. Zhang, Z.; Huo, Y.; Zhou, Z.; Zhang, P.; Hu, J. Role of lncRNA PART1 in intervertebral disc degeneration and associated underlying mechanism. Exp. Ther. Med. 2021, 21, 131. [CrossRef]

129. Gao, D.; Hao, L.; Zhao, Z. Long non-coding RNA PART1 promotes intervertebral disc degeneration through regulating the miR-93/MMP2 pathway in nucleus pulposus cells. Int. J. Mol. Med. 2020, 46, 289-299. [CrossRef]

130. Chen, J.; Jia, Y.S.; Liu, G.Z.; Sun, Q.; Zhang, F.; Ma, S.; Wang, Y.J. Role of LncRNA TUG1 in intervertebral disc degeneration and nucleus pulposus cells via regulating Wnt/ $\beta$-catenin signaling pathway. Biochem. Biophys. Res. Commun. 2017, 491, 668-674. [CrossRef]

131. Wang, Y.; Song, Q.; Huang, X.; Chen, Z.; Zhang, F.; Wang, K.; Huang, G.; Shen, H. Long noncoding RNA GAS5 promotes apoptosis in primary nucleus pulposus cells derived from the human intervertebral disc via Bcl-2 downregulation and caspase-3 upregulation. Mol. Med. Rep. 2019, 19, 2164-2172. [CrossRef] [PubMed]

132. Li, X.; Lou, Z.; Liu, J.; Li, H.; Lei, Y.; Zhao, X.; Zhang, F. Upregulation of the long noncoding RNA lncPolE contributes to intervertebral disc degeneration by negatively regulating DNA polymerase epsilon. Am. J. Transl. Res. 2019, 11, $2843-2854$.

133. Cheng, X.; Zhang, L.; Zhang, K.; Zhang, G.; Hu, Y.; Sun, X.; Zhao, C.; Li, H.; Li, Y.M.; Zhao, J. Circular RNA VMA21 protects against intervertebral disc degeneration through targeting miR-200c and $\mathrm{X}$ linked inhibitor-of-apoptosis protein. Ann. Rheum. Dis. 2018, 77, 770-779. [CrossRef] [PubMed]

134. Song, J.; Wang, H.L.; Song, K.H.; Ding, Z.W.; Wang, H.L.; Ma, X.S.; Lu, F.Z.; Xia, X.L.; Wang, Y.W.; Fei, Z.; et al. CircularRNA_104670 plays a critical role in intervertebral disc degeneration by functioning as a ceRNA. Exp. Mol. Med. 2018, 50, 1-12. [CrossRef] [PubMed]

135. Hayashi, H.; Okada, K.; Hashimoto, J.; Tada, K.; Ueno, R. Cervical spondylotic myelopathy in the aged patient. A radiographic evaluation of the aging changes in the cervical spine and etiologic factors of myelopathy. Spine 1988, 13, 618-625. [CrossRef] [PubMed]

136. Kumar, V.G.; Rea, G.L.; Mervis, L.J.; McGregor, J.M. Cervical spondylotic myelopathy: Functional and radiographic long-term outcome after laminectomy and posterior fusion. Neurosurgery 1999, 44, 771-777; discussion 777-778. [CrossRef]

137. Hsieh, A.H.; Yoon, S.T. Update on the pathophysiology of degenerative disc disease and new developments in treatment strategies. Open Access J. Sports Med. 2010, 1, 191-199. [CrossRef]

138. Liu, S.; Yang, S.D.; Huo, X.W.; Yang, D.L.; Ma, L.; Ding, W.Y. 17ß-Estradiol inhibits intervertebral disc degeneration by downregulating MMP-3 and MMP-13 and up-regulating type II collagen in a rat model. Artif. Cells Nanomed. Biotechnol. 2018, 46, 182-191. [CrossRef] 
139. Fu, H.Y.; Shen, L.; Gao, X.S.; Cui, D.X.; Cui, Z.Y. SF1670 inhibits apoptosis and inflammation via the PTEN/Akt pathway and thus protects intervertebral disc degeneration. Eur. Rev. Med. Pharmacol. Sci. 2020, 24, 8694-8702. [CrossRef]

140. Zhang, Q.; Li, J.; Li, Y.; Che, H.; Chen, Y.; Dong, J.; Xian, C.J.; Miao, D.; Wang, L.; Ren, Y. Bmi deficiency causes oxidative stress and intervertebral disc degeneration which can be alleviated by antioxidant treatment. J. Cell Mol. Med. 2020, $24,8950-8961$. [CrossRef]

141. Kakiuchi, Y.; Yurube, T.; Kakutani, K.; Takada, T.; Ito, M.; Takeoka, Y.; Kanda, Y.; Miyazaki, S.; Kuroda, R.; Nishida, K. Pharmacological inhibition of mTORC1 but not mTORC2 protects against human disc cellular apoptosis, senescence, and extracellular matrix catabolism through Akt and autophagy induction. Osteoarthr. Cartil. 2019, 27, 965-976. [CrossRef] [PubMed]

142. Ito, M.; Yurube, T.; Kakutani, K.; Maeno, K.; Takada, T.; Terashima, Y.; Kakiuchi, Y.; Takeoka, Y.; Miyazaki, S.; Kuroda, R.; et al Selective interference of mTORC1/RAPTOR protects against human disc cellular apoptosis, senescence, and extracellular matrix catabolism with Akt and autophagy induction. Osteoarthr. Cartil. 2017, 25, 2134-2146. [CrossRef] [PubMed]

143. Kang, L.; Liu, S.; Li, J.; Tian, Y.; Xue, Y.; Liu, X. The mitochondria-targeted anti-oxidant MitoQ protects against intervertebral disc degeneration by ameliorating mitochondrial dysfunction and redox imbalance. Cell Prolif. 2020, 53, e12779. [CrossRef] [PubMed]

144. Huang, H.; Cheng, S.; Zheng, T.; Ye, Y.; Ye, A.; Zhu, S.; Lin, X. Vitamin D retards intervertebral disc degeneration through inactivation of the NF-KB pathway in mice. Am. J. Transl. Res. 2019, 11, 2496-2506. [PubMed]

145. Lin, J.; Zhuge, J.; Zheng, X.; Wu, Y.; Zhang, Z.; Xu, T.; Meftah, Z.; Xu, H.; Wu, Y.; Tian, N.; et al. Urolithin A-induced mitophagy suppresses apoptosis and attenuates intervertebral disc degeneration via the AMPK signaling pathway. Free Radic. Biol. Med. 2020, 150, 109-119. [CrossRef]

146. Liu, X.; Zhuang, J.; Wang, D.; Lv, L.; Zhu, F.; Yao, A.; Xu, T. Glycyrrhizin suppresses inflammation and cell apoptosis by inhibition of HMGB1 via p38/p-JUK signaling pathway in attenuating intervertebral disc degeneration. Am. J. Transl. Res. 2019, 11, 5105-5113.

147. Li, X.; Liu, X.; Wang, Y.; Cao, F.; Chen, Z.; Hu, Z.; Yu, B.; Feng, H.; Ba, Z.; Liu, T.; et al. Intervertebral disc degeneration in mice with type II diabetes induced by leptin receptor deficiency. BMC Musculoskelet. Disord. 2020, 21, 77. [CrossRef]

148. Presciutti, S.M.; Paglia, D.N.; Karukonda, T.; Soung do, Y.; Guzzo, R.; Drissi, H.; Moss, I.L. PDGF-BB inhibits intervertebral disc cell apoptosis in vitro. J. Orthop. Res. 2014, 32, 1181-1188. [CrossRef]

149. Liu, W.; Jin, S.; Huang, M.; Li, Y.; Wang, Z.; Wang, P.; Zhao, X.; Xia, P.; Feng, J. Duhuo jisheng decoction suppresses matrix degradation and apoptosis in human nucleus pulposus cells and ameliorates disc degeneration in a rat model. J. Ethnopharmacol. 2020, 250, 112494. [CrossRef]

150. Shi, L.; Teng, H.; Zhu, M.; Li, C.; Huang, K.; Chen, B.I.; Dai, Y.; Wang, J. Paeoniflorin inhibits nucleus pulposus cell apoptosis by regulating the expression of Bcl-2 family proteins and caspase-9 in a rabbit model of intervertebral disc degeneration. Exp. Ther. Med. 2015, 10, 257-262. [CrossRef] 